\title{
Variations in Carotenoids, Vitamins A and E, and Color in Cow's Plasma and Milk During Late Pregnancy and the First Three Months of Lactation
}

\author{
F. Calderón, B. Chauveau-Duriot, B. Martin, B. Graulet, M. Doreau, and P. Nozière ${ }^{1}$ \\ Institut National de la Recherche Agronomique (INRA), UR1213 Unité de Recherche sur les Herbivores, \\ F-63122 St Genès Champanelle, France
}

\begin{abstract}
The main aim of this work was to assess the effect of lactation period on the secretion of carotenoids in cow's milk. Our objective was to determine the variations in carotenoids in the plasma and milk of dairy cows from drying off to wk 12 of lactation, and to specify whether these variations depend on body stores of these micronutrients at calving. We also investigated the relationship between $\beta$-carotene (BC) and color in plasma and milk to evaluate the methods based on direct or indirect characterization of these micronutrients for traceability of feeding management. The experiment was carried out on 18 dairy cows, which were dried off 8 wk before their expected date of parturition. They were then divided into 2 homogeneous groups and fed diets contrasting in carotenoid content, high (grass silage) vs. low (corn silage), from wk -7 until parturition. From parturition through wk 12 of lactation, both groups received a grass silage-based diet. Variations in concentrations of carotenoids and the color index (CI) in plasma and milk were monitored from drying off to wk 12 of lactation. Other components of nutritional interest (i.e., vitamins $\mathrm{A}$ and $\mathrm{E}$ ) were also measured. Lutein, all-trans $\mathrm{BC}$ and cis-13 BC were the carotenoids found in plasma and milk. Plasma concentrations of carotenoids, vitamin $\mathrm{A}$, and vitamin $\mathrm{E}$ decreased throughout the dry period and in the first week of lactation, then increased through the first 3 mo of lactation, parallel to grass silage intake. For both groups, carotenoid and vitamin concentrations in milk drastically decreased during the first week of lactation, then did not vary significantly throughout the remainder to the experiment (wk 12). Plasma concentrations of carotenoids and vitamins were higher in the high-carotenoid group than in the low-carotenoid group during the dry period. Those differences were also observed in colostrum and disappeared in both plasma and milk during
\end{abstract}

Received September 27, 2006.

Accepted January 15, 2007.

${ }^{1}$ Corresponding author: noziere@clermont.inra.fr the first $10 \mathrm{~d}$ of the lactation period. This work allowed us to conclude that, unlike in plasma, variations in carotenoids, vitamin $\mathrm{A}$, and vitamin $\mathrm{E}$ in milk were only slight in early lactation. In both plasma and milk, the concentrations were only transitorily affected by the nature of forage fed during the dry period, showing that they depended mainly on the dietary supply, even during the lipid mobilization period. The relationship between concentrations of $\mathrm{BC}$ and the $\mathrm{CI}$ was linear in plasma $\left(R^{2}=0.51\right)$ and milk $\left(R^{2}=0.37\right)$ and reached a plateau in the milk + colostrum data set $\left(R^{2}=0.77\right)$. The changes in CI during the first 3 mo of lactation were not negligible compared with variations related to the nature of forage reported in previous studies. This implies that methods being developed for the traceability of feeding management of dairy cows based on direct or indirect characterization of these micronutrients in milk, plasma, or both will need to account for changes in relation to lactation stage, which requires further investigation.

Key words: carotenoid, vitamin E, lactation stage, dairy cow

\section{INTRODUCTION}

In certain dairy product marketing sectors, the nature of the animal diet is increasingly considered by the consumer as an important criterion in the nutritional or sensory quality of the products, or both. In particular, consumer perception is very positive for grass-based diets, which is related to specific compounds of nutritional or sensory interest (Martin et al., 2004). In dairy products, along with certain fatty acids, carotenoids and fat-soluble vitamins are recognized as tracer compounds indicating animal feeding management (Martin et al., 2005a). Carotenoids influence the sensory properties of dairy products not only indirectly via antioxidant activity, but also directly because they confer a yellow color that is perceived positively (Prache et al., 2002). Hence, a simple method based on quantifying the carotenoid pigment signature by a color index (CI), calculated from absorbance (plasma) or reflectance (milk) spectra between 450 and $530 \mathrm{~nm}$, has been developed 
as a tool to trace feeding management in ruminants (Prache et al., 2002). This method has given promising results on individual samples of cow's milk and plasma (Martin et al., 2005a; Nozière et al., 2006b) as well as butter and cheese (Martin et al., 2005b), but the respective influences of dietary and nondietary factors on carotenoid concentrations and their associated color in milk remain to be clarified.

Type of forage is the main factor affecting the $\beta$ carotene (BC) concentration and color in cow's plasma and milk in midlactation, whereas parity, production level, and udder health status appear to have only a limited effect (as reviewed by Nozière et al., 2006a). Although lactation stage may be an important factor in terms of concentrations of fat-soluble micronutrients in both plasma and milk, its effect has never been clearly quantified because of a lack of relevant data. Indeed, most experiments have focused on plasma BC, vitamin $\mathrm{A}$, and vitamin $\mathrm{E}$ during the peripartum period, with the objective of achieving suitable plasma levels to maintain the cow's health and prevent reproductive disorders (Johnston and Chew, 1984; Michal et al., 1994; Baldi, 2005) while ensuring an adequate vitamin supply to calves via colostrum (Goff and Stabel, 1990). In contrast, there have been few reports documenting changes in carotenoid and fat-soluble vitamin concentrations in milk during early and midlactation, and the results available appear contradictory. In Denmark, Jensen et al. (1999) reported a high increase in plasma and milk concentrations as well as milk yield of BC, vitamin $\mathrm{A}$, and vitamin $\mathrm{E}$ throughout the first $6 \mathrm{mo}$ of lactation in primiparous cows, whereas in New Zealand, Waghorn and Knight (1992) and Winkelman et al. (1999) reported a continuous decrease in BC yield that followed fat yield. The discrepancy between these results may result from differences in the level of carotenoids stored in body fat at the beginning of lactation and in the evolution of carotenoid intake throughout lactation, which may differ widely between feeding systems but were not documented.

Therefore, the main objective of this work was to determine the variations in carotenoid, vitamin $\mathrm{A}$, and vitamin $\mathrm{E}$ concentrations in plasma and milk from drying off through the third month of lactation. To account for these components potentially being restored by adipose tissues during the period of lipid mobilization, the experiment was conducted on 2 groups of dairy cows fed high-vs. low-carotenoid diets during the dry period. The relationships between $\mathrm{BC}$ and $\mathrm{CI}$ in both plasma and milk were also investigated based on direct or indirect characterization of these micronutrients in milk, plasma, or both to evaluate the methods used in terms of traceability of feeding management in dairy cows.

\section{MATERIALS AND METHODS}

\section{Animals, Treatments, and Experimental Design}

The experiment was conducted on an experimental farm of the French National Agronomic Research Institute (INRA, Theix, France) on 18 multiparous Holstein dairy cows scheduled for calving between October 2004 and March 2005. Before drying off, the cows were fed a high-carotenoid diet consisting of pasture until the end of October, followed by a grass silage-based diet ad libitum. Cows were dried off 8 wk before their expected date of parturition and grazed a paddock before the beginning of stem elongation for $1 \mathrm{wk}$ (wk-8). They were then assigned to 2 homogeneous groups according to the date of drying off (October $16 \pm 51 \mathrm{~d}$ ), lactation number $(2.9 \pm 1.0)$, BW $(684 \pm 44 \mathrm{~kg}), \mathrm{BCS}(2.5 \pm 0.6$ on a scale of 0 to 5), mean milk yield and fat content over the whole previous lactation $(26.2 \pm 3.6 \mathrm{~kg} / \mathrm{d}$ and $42.1 \pm 4.3 \mathrm{~g} / \mathrm{kg}$, respectively), and the CI of plasma determined after the last milking $(89.1 \pm 36.4)$.

From wk -7 until parturition, the 2 groups were fed diets with contrasting carotenoid contents. The first group (HH) was fed on pasture until the end of October or until $3 \mathrm{wk}$ before the expected date of parturition, followed by a grass silage-based diet fed ad libitum (high-carotenoid diet). The second group (LH) was fed a corn silage-based diet ad libitum (low-carotenoid diet), including $1 \mathrm{~kg} / \mathrm{d}$ of late hay, $200 \mathrm{~g} / \mathrm{d}$ of urea, and 100 $\mathrm{g} / \mathrm{d}$ of sodium bicarbonate. In both groups, $1 \mathrm{~kg} / \mathrm{d}$ (wk $-2)$ and then $2 \mathrm{~kg} / \mathrm{d}(\mathrm{wk}-1)$ of concentrate was provided individually.

From parturition until wk 12 of lactation, both groups were individually fed a grass silage-based diet (highcarotenoid diet). Grass silage was the same as before parturition and consisted of a mixture of first-cut perennial ryegrass and natural grassland harvested in June 2004 and ensiled without wilting. No acidic preservative was used to avoid oxidation of carotenoids. To ensure that all cows received the same amount of carotenoids, the amount of silage distributed was limited and was similar for each cow, increasing progressively from $7.6 \mathrm{~kg}$ of $\mathrm{DM} / \mathrm{d}$ (wk 1) to $14.0 \mathrm{~kg}$ of DM/d (wk 10 to 12 ). A concentrate mixture and soybean meal were provided and adjusted daily to reach individual energy and nitrogen requirements for lactation. Each animal received $200 \mathrm{~g} / \mathrm{d}$ of a mineral-vitamin mix $(4.5 \% \mathrm{P}, 20 \%$ $\mathrm{Ca}, 4.5 \% \mathrm{Mg}, 5 \% \mathrm{Na}, 1,300 \mathrm{mg} / \mathrm{kg}$ of $\mathrm{Cu}, 6,000 \mathrm{mg} / \mathrm{kg}$ of $\mathrm{Zn}, 3,500 \mathrm{mg} / \mathrm{kg}$ of $\mathrm{Mn}, 80 \mathrm{mg} / \mathrm{kg}$ of I, $32 \mathrm{mg} / \mathrm{kg}$ of Co, $20 \mathrm{mg} / \mathrm{kg}$ of Se, $600,000 \mathrm{IU} / \mathrm{kg}$ of vitamin A, 120,000 $\mathrm{IU} / \mathrm{kg}$ of vitamin $\mathrm{D}_{3}$, and $1,300 \mathrm{IU} / \mathrm{kg}$ of vitamin $\mathrm{E}$ ).

Feed composition, nutritive value, and carotenoid concentrations are given in Table 1. Vitamin E was not determined in feeds. This study was carried out in 
Table 1. Composition and nutritive value of feeds

\begin{tabular}{lccccc}
\hline & $\begin{array}{c}\text { Grass } \\
\text { silage }\end{array}$ & $\begin{array}{c}\text { Corn } \\
\text { silage }\end{array}$ & Hay & $\begin{array}{c}\text { Soybean } \\
\text { meal }\end{array}$ & Concentrate $^{2}$ \\
\hline DM (g/kg) & 227 & 272 & 854 & 895 & 891 \\
OM (g/kg of DM) & 890 & 944 & 953 & 933 & 924 \\
CP (g/kg of DM) & 138 & 86 & 56 & 518 & 185 \\
Crude fiber (g/kg of DM) & 330 & 188 & 382 & 58 & 95 \\
NDF (g/kg of DM) & 557 & 375 & 709 & 112 & 216 \\
ADF (g/kg of DM) & 358 & 186 & 435 & 69 & 125 \\
OM digestibility (\%) & 71 & 75 & 52 & 90 & 7.12 \\
Net energy (MJ/kg of DM) & 6.07 & 6.70 & 4.19 & 8.33 & 129 \\
PDIN (g/kg of DM) & 77 & 51 & 35 & 371 & 0.3 \\
PDIE (g/kg of DM) & 60 & 69 & 58 & 260 & 0.3 \\
Carotenoids ( $\mu$ g/g of DM) & 517 & 68 & 21 & 0.3 & 0 \\
Lutein & 250 & 25 & 18 & 0.3 & 0 \\
Zeaxanthin & 53 & 9.8 & 1.7 & 0 & 0 \\
Violaxanthin & 59 & 0 & 0 & 0 & 0 \\
Antheraxanthin & 21 & 0 & 0 & 0 & 0 \\
Unknown xanthophyll & 28 & 9.6 & 1.4 & 0 & 0 \\
All-trans $\beta$-carotene & 106 & 24 & 0 & 0 & 0 \\
\hline
\end{tabular}

\footnotetext{
${ }^{1}$ Dry matter was determined by drying at $103^{\circ} \mathrm{C}$ for $24 \mathrm{~h}$. Organic matter was determined by drying at $550^{\circ} \mathrm{C}$ for $6 \mathrm{~h}$. Crude protein was determined by the Kjeldahl method (AOAC, 1990). Crude fiber was determined by the method of Wende (AOAC, 1990). Neutral detergent fiber and ADF were determined by the method of Van Soest and Robertson (AOAC, 1990). Organic matter digestibility, net energy, and nitrogen values were calculated according to INRA guidelines (1989). PDIN = proteins digestible in the intestines, when degraded $\mathrm{N}$ is a limiting factor; PDIE = proteins digestible in the intestines, when energy is a limiting factor. Carotenoids were determined according to the method of Cardinault et al. (2006). Unknown xanthophyll was quantified according to an epilutein standard that presented the same retention time and molecular mass.

${ }^{2}$ Concentrate: $6,000 \mathrm{IU} / \mathrm{kg}$ of vitamin A, 1,250 IU/kg of vitamin $\mathrm{D}_{3}$, and $15 \mathrm{IU} / \mathrm{kg}$ of vitamin $\mathrm{E}$.
}

accordance with French Ministry of Agriculture guidelines on the use of animals for experimental purposes.

\section{Sampling and Measurements}

Intake was recorded individually on $4 \mathrm{~d} / \mathrm{wk}$. The DM $\left(103^{\circ} \mathrm{C}\right.$ for $\left.24 \mathrm{~h}\right)$ was determined 4 times a week for silages and once a week for hay, soybean meal, and concentrate. The DMI was corrected for losses in volatile compounds in silages during oven drying (VFA, lactate, ammonia, alcohols) according to INRA procedures (INRA, 1981). A representative sample of each feed was kept in the dark under vacuum, at $-15^{\circ} \mathrm{C}$ for silages or at $+4^{\circ} \mathrm{C}$ for hay and concentrates, until carotenoid determination.

Individual plasma samples (from caudal blood withdrawn before the morning meal using L-heparin as an anticoagulant) were collected from cows before ( $\mathrm{d}-56$, -28 , and -7) and after parturition (d 1, 3, 5, 7, 10, 21, $28,42,56,70$, and 84 ), and from newborn calves before their first meal. Cows were milked twice daily at 6 a.m. and 4 p.m., and individual milk yields were recorded daily from $\mathrm{d} 1$ to 10 and then 4 times per week from wk 3 to 12 . Individual milk samples were collected (morning and evening) on d 1, 2, 3, 4, 5, 7, and 10, and then twice a week from wk 3 to 12 to determine the milk fat and protein contents (AOAC, 1990) by infrared spectrophotometry (MilkoScan 4000, Foss Systems, Hillerød, Denmark).

The CI were determined immediately after sampling, by absorbance for plasma using a spectrophotometer (Hitachi U-2000, Hitachi Ltd., Tokyo, Japan), and by reflectance for morning milk using a spectrocolorimeter (Minolta CM 2002, Minolta France S. A., Carrières-surSeine, France), as previously described (Prache et al., 2002; Nozière et al., 2006b). Briefly, the spectrum between 450 and $530 \mathrm{~nm}$ was translated to make the absorbance (plasma) or reflectance (milk) value at 530 $\mathrm{nm}$ equal to zero, and the CI corresponded to the absolute value of the integral of the translated spectrum between 450 and $530 \mathrm{~nm}$. Plasma and morning milk samples were stored at $-15^{\circ} \mathrm{C}$ away from light until carotenoid, vitamin (plasma and milk), and NEFA (plasma) analysis. Carotenoid, vitamin A, and vitamin E concentrations were determined by HPLC using the technique described by Lyan et al. (2001) for plasma, modified according to Nozière et al. (2006b) for milk and according to Cardinault et al. (2006) for feedstuffs. All extractions were performed under yellow light at room temperature, using echinenone as an internal standard. The HPLC apparatus consisted of a Waters Alliance 2996 HPLC system (Waters SA, Saint Quentin-en-Yvelines, France) with photodiode array detector monitoring between 280 and $600 \mathrm{~nm}$. Carotenoids, vita- 
$\min \mathrm{A}$, and vitamin $\mathrm{E}$ were simultaneously separated on a $150 \times 4.6 \mathrm{~mm}, \mathrm{RP} \mathrm{C} 18,3-\mu \mathrm{m}$ Nucleosil column coupled with a $250 \times 4.6 \mathrm{~mm}, \mathrm{RP}$ C18, $5-\mu \mathrm{m}$ Vydac TP54 column (Interchim, Montluçon, France), as previously described (Calderón et al., 2006). Millenium 32 software (version 3.05.01) from Waters SA was used for instrument control, data acquisition, and data processing. Wavelength detection for carotenoids, vitamin $\mathrm{A}$, and vitamin $\mathrm{E}$ was performed at 450, 325, and $292 \mathrm{~nm}$, respectively, and the compounds were identified by comparing retention times and spectral analyses with those of pure standards (>95\%). Concentrations of the compounds were calculated using an external standard curve and were then adjusted by percentage recovery of the added internal standard. Plasma NEFA concentrations were determined using an enzymatic kit (NEFA C ACS-ACOD Method enzymatic color test; Wako Chemicals GmbH, Neuss, Germany) on d -28 , $-7,1,5,10,21$, and 42 .

\section{Statistical Analysis}

Milks concentrations of fat-soluble micronutrients were expressed as micrograms per milliliter, or were related to milk fat content and expressed as micrograms per gram of fat. Data were statistically analyzed as repeated measurements using the MIXED procedure of the SAS software package (SAS Institute, 2000), with group (corresponding to the type of silage fed before calving: HH vs. LH), time (corresponding to the week or day/parturition), and their interaction as fixed effects, and animal as a random effect. A $P$-value of $<0.05$ was considered significant and a $P$-value of $<0.10$ was considered a trend. Means separation was performed using the PDIFF option of the LSMeans procedure of SAS (SAS Institute, 2000). The experimental unit used for intake, milk yield, and milk fat and protein contents was the mean per animal per week. The experimental unit used for micronutrient concentrations and percentages, CI in plasma and milk, plasma NEFA, and milk micronutrient yield was the mean per animal per day. For intake and for plasma micronutrients and CI, prepartum (d -56 to 1 ) and postpartum (d 1 to 84 ) data were analyzed separately.

The global relationships between $\mathrm{BC}$ or total carotenoid concentrations and CI in plasma, colostrum, and milk were assessed by regressions. Within-animal relationships were assessed by variance-covariance models with animal as a fixed effect using the GLM procedure of the SAS software package (SAS Institute, 2000).

\section{RESULTS \\ Intake, Milk Yield and Composition, and Plasma NEFA}

Changes in DM and silage intakes, milk yield, and milk fat throughout the experiment are presented in
Figure 1. During the dry period, daily intake of DM, $\mathrm{NE}_{\mathrm{L}}$, and digestible protein were lower $(P<0.001)$ under $\mathrm{HH}$ than $\mathrm{LH}$, averaging $11.9(\mathrm{SE}=0.5)$ vs. 14.6 $(\mathrm{SE}=0.5) \mathrm{kg}$ of $\mathrm{DM}, 69.9(\mathrm{SE}=3.2)$ vs. $89.6(\mathrm{SE}=3.0)$ $\mathrm{MJ}$ of $\mathrm{NE}_{\mathrm{L}}$, and $758(\mathrm{SE}=45)$ vs. $987(\mathrm{SE}=44) \mathrm{g}$ of protein digestible in the intestines (PDI), respectively. This corresponded to 125 vs. $157 \%$ and 122 vs. $159 \%$ of $\mathrm{NE}_{\mathrm{L}}$ and PDI requirements, respectively. Daily intake of carotenoids was higher $(P<0.001)$ under $\mathrm{HH}$ than $\mathrm{LH}$, averaging $2,658(\mathrm{SE}=100)$ vs. $322(\mathrm{SE}=95)$ $\mathrm{mg}$ of lutein, $567(\mathrm{SE}=21)$ vs. $120(\mathrm{SE}=20) \mathrm{mg}$ of zeaxanthin, $622(\mathrm{SE}=23)$ vs. $0(\mathrm{SE}=22) \mathrm{mg}$ of violaxanthin, $221(\mathrm{SE}=8)$ vs. $0(\mathrm{SE}=8) \mathrm{mg}$ of antheraxanthin, $1,125(\mathrm{SE}=42)$ vs. $295(\mathrm{SE}=40) \mathrm{mg}$ of all-trans $\mathrm{BC}$, and $293(\mathrm{SE}=11)$ vs. $117(\mathrm{SE}=11) \mathrm{mg}$ of an unknown xanthophyll quantified according to an epilutein standard that had the same retention time and molecular mass.

During the first 12 wk of lactation, intake of DM, $\mathrm{NE}_{\mathrm{L}}$, digestible protein, and carotenoids progressively increased with time (Table 2). Except in wk 3, 10, and 12 , when grass silage intake was transitorily $9 \%(P=$ $0.048), 7 \%(P=0.033)$, and $7 \%(P=0.059)$ higher under $\mathrm{HH}$ than $\mathrm{LH}$, the intakes of $\mathrm{DM}, \mathrm{NE}_{\mathrm{L}}$, digestible protein, and carotenoids were not significantly different between groups. On average for both groups, intake corresponded to 48 and $49 \%$ (wk 1), 77 and 90\% (wk 6), and 88 and $101 \%$ (wk 12) of $\mathrm{NE}_{\mathrm{L}}$ and PDI requirements, respectively.

Milk yield, milk fat content and yield, and milk protein content and yield were similar between groups (Table 2). Between wk 1 and 6 , milk yield increased ( $P$ $<0.001$ ) from 25.8 to $37.1 \mathrm{~kg} / \mathrm{d}$, whereas milk fat and protein contents decreased $(P<0.001)$ from 57.5 to 40.1 $\mathrm{g} / \mathrm{kg}$, and from 52.0 to $27.8 \mathrm{~g} / \mathrm{kg}$, respectively, on average, for both groups. On wk 12, milk yield and milk fat and protein contents reached $32.9 \mathrm{~kg} / \mathrm{d}, 39.6 \mathrm{~g} / \mathrm{kg}$, and $28.8 \mathrm{~g} / \mathrm{kg}$, respectively, on average, for both groups. There were no significant between-group differences in plasma NEFA concentrations, which averaged 58, 287, 817, 790, 837, and $215 \mu M(\mathrm{SE}=60 \mu M)$ at $\mathrm{d}-7,1,5$, 10,21 , and 42 , respectively.

\section{Plasma Carotenoids, Vitamins $A$ and E, and $\mathrm{Cl}$ in Cows}

Lutein, all-trans $\mathrm{BC}$, and cis-13 $\mathrm{BC}$ were the 3 carotenoids found in plasma. During the dry period, plasma concentrations tended to be higher $(P<0.10)$ under $\mathrm{HH}$ than $\mathrm{LH}$ for all-trans $\mathrm{BC}$, cis-13 $\mathrm{BC}$, vitamin $\mathrm{E}(P<$ $0.10)$, and CI $(P<0.10)$, whereas they were not significantly different for lutein and vitamin A (Figure 2). Throughout the dry period, there were significant decreases in plasma concentrations of lutein $(P<0.10)$, 

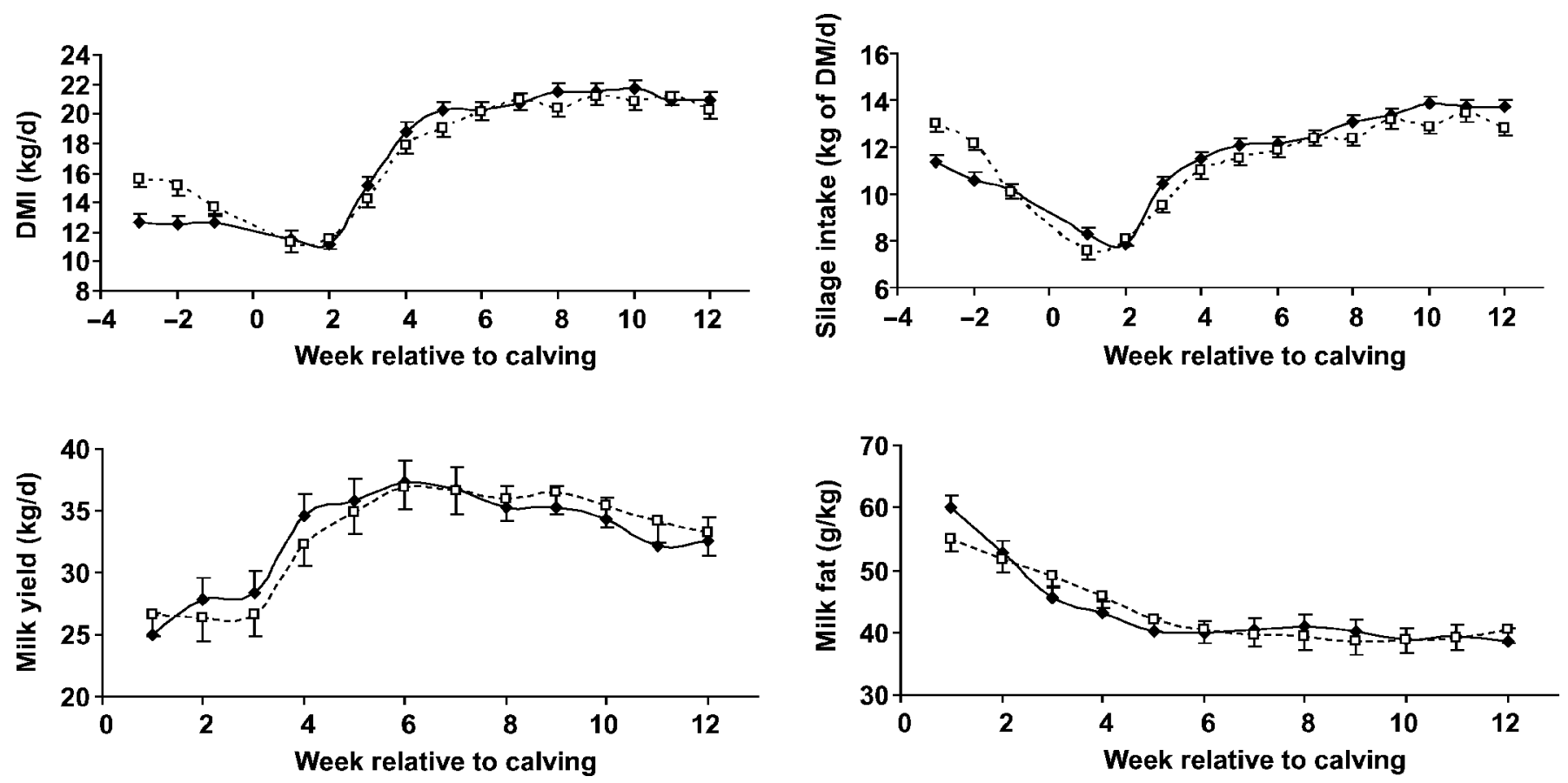

Figure 1. Changes in DM and silage intakes, milk yield, and milk fat in dairy cows. Cows were maintained on grass silage ( $\bullet$ ) or shifted to corn silage ( $\square) 7 \mathrm{wk}$ before calving. Both groups were fed grass silage after calving. Means \pm SE for 9 cows per group.

Table 2. Intake, milk production, and milk composition of cows fed grass silage in selected weeks of early lactation $^{1}$

\begin{tabular}{|c|c|c|c|c|c|c|c|c|}
\hline \multirow[b]{2}{*}{ Item } & \multicolumn{4}{|c|}{ Week of lactation } & \multirow[b]{2}{*}{$\mathrm{SE}^{2}$} & \multicolumn{3}{|c|}{ Effects $^{2}$} \\
\hline & Group & 1 & 6 & 12 & & Group & Time & Group $\times$ time \\
\hline \multicolumn{9}{|l|}{ Intake } \\
\hline \multirow[t]{2}{*}{$\mathrm{DM}(\mathrm{kg} / \mathrm{d})$} & $\mathrm{HH}$ & 11.5 & 20.2 & 20.9 & & & & \\
\hline & LH & 11.3 & 20.2 & 20.2 & 0.6 & 0.457 & $<0.001$ & 0.031 \\
\hline \multirow[t]{2}{*}{ Net energy $(\mathrm{MJ} / \mathrm{d})$} & $\mathrm{HH}$ & 70 & 129 & 132 & & & & \\
\hline & LH & 69 & 129 & 129 & 4 & 0.524 & $<0.001$ & 0.028 \\
\hline \multirow[t]{2}{*}{ Protein $\left(\mathrm{g}\right.$ of $\left.\mathrm{PDI}^{3} / \mathrm{d}\right)$} & $\mathrm{HH}$ & 961 & 1,969 & 2,004 & & & & \\
\hline & LH & 955 & 1,986 & 1,972 & 69 & 0.670 & $<0.001$ & 0.031 \\
\hline \multirow[t]{2}{*}{ Total carotenoids (g/d) } & $\mathrm{HH}$ & 3.46 & 5.07 & 5.74 & & & & \\
\hline & $\mathrm{LH}$ & 3.17 & 4.95 & 5.35 & 0.14 & 0.077 & $<0.001$ & 0.076 \\
\hline \multirow[t]{2}{*}{ Milk yield (kg/d) } & $\mathrm{HH}$ & 24.9 & 37.3 & 32.6 & & & & \\
\hline & LH & 26.7 & 36.9 & 33.2 & 1.8 & 0.985 & $<0.001$ & 0.346 \\
\hline \multirow[t]{2}{*}{ Milk yield $4 \%(\mathrm{~kg} / \mathrm{d})$} & $\mathrm{HH}$ & 32.7 & 37.2 & 31.8 & & & & \\
\hline & LH & 32.9 & 37.0 & 33.2 & 2.0 & 0.968 & $<0.001$ & 0.920 \\
\hline \multirow[t]{2}{*}{ Milk fat (g/kg) } & $\mathrm{HH}$ & 59.9 & 39.9 & 38.7 & & & & \\
\hline & LH & 55.1 & 40.3 & 40.4 & 2.0 & 0.990 & $<0.001$ & 0.321 \\
\hline \multirow[t]{2}{*}{ Fat yield (g/d) } & $\mathrm{HH}$ & 1,511 & 1,484 & 1,252 & & & & \\
\hline & LH & 1,479 & 1,484 & 1,329 & 93 & 0.957 & $<0.001$ & 0.949 \\
\hline \multirow[t]{2}{*}{ Milk protein (g/kg) } & $\mathrm{HH}$ & 54.0 & 28.0 & 28.9 & & & & \\
\hline & LH & 50.0 & 27.6 & 28.7 & 1.4 & 0.852 & $<0.001$ & 0.372 \\
\hline \multirow[t]{2}{*}{ Protein yield (g/d) } & $\mathrm{HH}$ & 1,341 & 1,036 & 932 & & & & \\
\hline & LH & 1,338 & 1,027 & 948 & 68 & 0.913 & $<0.001$ & 0.992 \\
\hline
\end{tabular}

${ }^{1}$ Groups differed according to the nature of forage fed during the drying-off period ( 8 wk before calving): grass silage $(\mathrm{HH})$ or corn silage $(\mathrm{LH})$. Values are means for 9 cows per group. Standard error values are pooled SE for each group $\times$ time mean.

${ }^{2}$ Statistical analysis performed on the whole lactation period (wk 1 to 12 ).

${ }^{3} \mathrm{PDI}=$ proteins digestible in the intestine. 

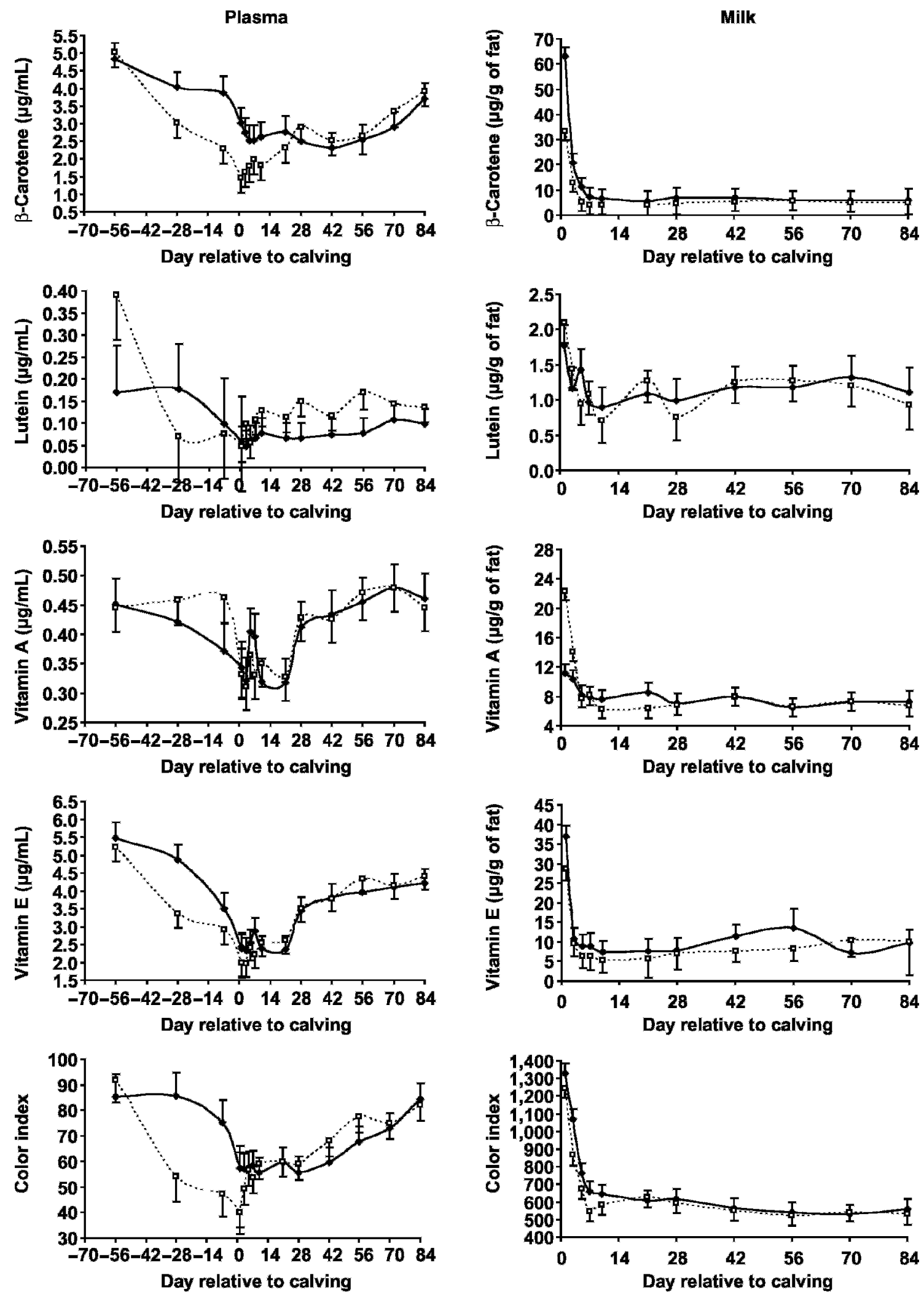

Figure 2. Changes in $\beta$-carotene, lutein, vitamin $\mathrm{A}$, vitamin $\mathrm{E}$, and the color index in plasma and milk of dairy cows. Cows were maintained on grass silage $(\checkmark)$ or shifted to corn silage $(\square) 7 \mathrm{wk}$ before calving. Both groups were fed grass silage after calving. Means \pm SE for 9 cows per group. 
all-trans $\mathrm{BC}(P<0.001)$, cis-13 $\mathrm{BC}(P<0.01)$, vitamin $\mathrm{A}(P<0.05)$, and vitamin $\mathrm{E}(P<0.001)$ as well as in $\mathrm{CI}$ $(P<0.001)$. For BC and CI, the group $\times$ time interactions were significant $(P<0.10$ and $P<0.05$, respectively), reflecting that these decreases occurred from $d-56$ under LH and mainly during the last week under HH. The same trend was observed for lutein $(P=0.12)$.

At calving, plasma concentrations were higher in the $\mathrm{HH}$ group than the LH group for all-trans $\mathrm{BC}(2.15 \mathrm{vs}$. $0.98 \mu \mathrm{g} / \mathrm{mL}, P<0.01)$, cis $-13 \mathrm{BC}(0.86$ vs. $0.49 \mu \mathrm{g} / \mathrm{mL}$, $P<0.05)$, and CI (57.4 vs. $40.2, P<0.05)$. Differences between groups disappeared from d 3 for all-trans $\mathrm{BC}$ and $\mathrm{CI}$ and from d 10 for cis-13 BC. There were no significant between-group differences in plasma concentrations of lutein, vitamin $\mathrm{A}$, and vitamin $\mathrm{E}$ at calving (averaging $0.06,0.38$, and $2.20 \mu \mathrm{g} / \mathrm{mL}$, respectively) and throughout lactation, except at d 28 and 56, when lutein tended to be transitorily lower $(P<0.10)$ under the $\mathrm{HH}$ group than the LH group (0.07 vs. 0.15 and 0.08 vs. $0.17 \mu \mathrm{g} / \mathrm{mL}$, respectively).

For both groups, plasma concentrations of lutein $(P$ $<0.01)$, all-trans BC $(P<0.05)$, cis-13 BC $(P<0.001)$, vitamin $\mathrm{A}(P<0.001)$, and vitamin $\mathrm{E}(P<0.001)$ as well as CI $(P<0.01)$ increased between wk 1 and 12 of lactation, reaching an average of $0.12,2.68,1.13,0.45$, and $4.32 \mu \mathrm{g} / \mathrm{mL}$, and 83 units, respectively, at d 84 for both groups. Levels were not stabilized at d 84 for alltrans $\mathrm{BC}$, cis-13 $\mathrm{BC}$, and $\mathrm{CI}$, but were stabilized after d 7 for lutein, d 28 for vitamin A, and d 56 for vitamin E. Expressed as the percentage of total carotenoids, the respective proportions of lutein, cis-13 $\mathrm{BC}$, and all-trans $\mathrm{BC}$ remained constant from d 1 to 84 , averaging 4, 27, and $69 \%$, respectively.

\section{Plasma Carotenoids, Vitamin A, and Vitamin E in Newborn Calves}

Plasma concentrations of lutein, all-trans BC, cis-13 $\mathrm{BC}$, vitamin $\mathrm{A}$, and vitamin $\mathrm{E}$ in newborn calves were much lower than those in cows and were similar between HH- and LH-fed dams, averaging 0.020 (SE 0.006), 0.020 (SE 0.023), 0.007 (SE 0.007), 0.114 (SE 0.038 ), and 0.271 (SE 0.079$) \mu \mathrm{g} / \mathrm{mL}$ in both groups, respectively.

\section{Carotenoids, Vitamins $\mathrm{A}$ and $\mathrm{E}$, and $\mathrm{Cl}$ in Milk}

The effects of time and treatment on fat-soluble micronutrients in milk were similar regardless of units (micrograms per milliliter of milk or micrograms per gram of fat. Thus, only results expressed as micrograms per gram of fat are reported.

Lutein, cis-13 BC, and all-trans BC were the 3 carotenoids found in colostrum and milk. At calving, colos- trum fat concentrations were higher for all-trans BC (51.1 vs. $27.1 \mu \mathrm{g} / \mathrm{g}, P<0.001)$, cis-13 BC (11.8 vs. 6.4 $\mu \mathrm{g} / \mathrm{g}, P<0.001)$, and vitamin E (36.8 vs. $28.6 \mu \mathrm{g} / \mathrm{g}, P$ $<0.01)$ and lower for vitamin A (11.2 vs. $22.3 \mu \mathrm{g} / \mathrm{g}, P$ $<0.001$ ) in $\mathrm{HH}$ than in LH, respectively (Figure 2). Differences between groups disappeared from d 3 for all-trans $\mathrm{BC}$, cis-13 BC, and vitamin $\mathrm{E}$, and from d 5 for vitamin A. Lutein concentrations and CI were similar between groups at calving (averaging $1.94 \mu \mathrm{g} / \mathrm{g}$ of fat and 1,288 units, respectively) and throughout the experiment, except at d 3 , when CI was higher $(P<0.05)$ in the HH group than in the LH group (1,070 vs. 865, respectively).

For both groups, carotenoid, vitamin A, and vitamin E concentrations as well as CI decreased drastically during the first few days of lactation and stabilized from d 3 (lutein and vitamin E), d 5 (trans and cis-13 BC, vitamin A), or d 7 (CI) until wk 12 of lactation. At the end of the experiment, concentrations of lutein, alltrans $\mathrm{BC}$, cis-13 $\mathrm{BC}$, vitamin $\mathrm{A}$, and vitamin $\mathrm{E}$ in milk fat averaged 1.0, 4.4, 1.1, 6.9, and $9.9 \mu \mathrm{g} / \mathrm{g}$, and CI averaged 547, in both groups.

Expressed as the percentage of total carotenoids, lutein increased from 4.9 to $18.5 \%(P<0.001)$ and BC decreased from 95.1 to $81.5 \%(P<0.001)$ between $d 1$ and 7, after which there were no significant variations up to d 84, averaging $16.3 \%$ (lutein) and $83.6 \%$ (BC), respectively. The respective proportions of all-trans and cis-13 isomers in total BC remained constant from calving, averaging 78.6 and $21.3 \%$, respectively.

The amount of lutein secreted in milk showed no significant variation during the first $12 \mathrm{wk}$ of lactation. The amount of all-trans $\mathrm{BC}$, cis $\mathrm{BC}$, vitamin $\mathrm{A}$, and vitamin $\mathrm{E}$ secreted in milk decreased during the first few days of lactation and stabilized from $\mathrm{d} 3$ for vitamin $\mathrm{E}, \mathrm{d} 7$ for trans and cis-13 BC, and d 10 for vitamin A until wk 12 of lactation. There were no significant between-group differences in lutein and vitamin $\mathrm{E}$ from d 1, cis-13 BC from d 3, vitamin A from d 5, and trans BC from d 7 until wk 12 of lactation.

\section{Relationship Between Carotenoids and Color Index in Plasma, Colostrum, and Milk}

The relationships between $\mathrm{BC}$ concentrations and CI were linear in plasma and milk (including d 7 to 84), whereas they were exponential in colostrum (including d 1 to 5) and in the pooled milk + colostrum data set (Figure 3). Global regression analyses showed that BC concentrations explained $51,65,37$, and $77 \%$ of variations in CI in plasma, colostrum, milk, and milk + colostrum, with a root mean square error (RMSE) of 16, 216,81 , and 139 units of CI, respectively (Table 3). The within-animal models evidenced that the individual in- 

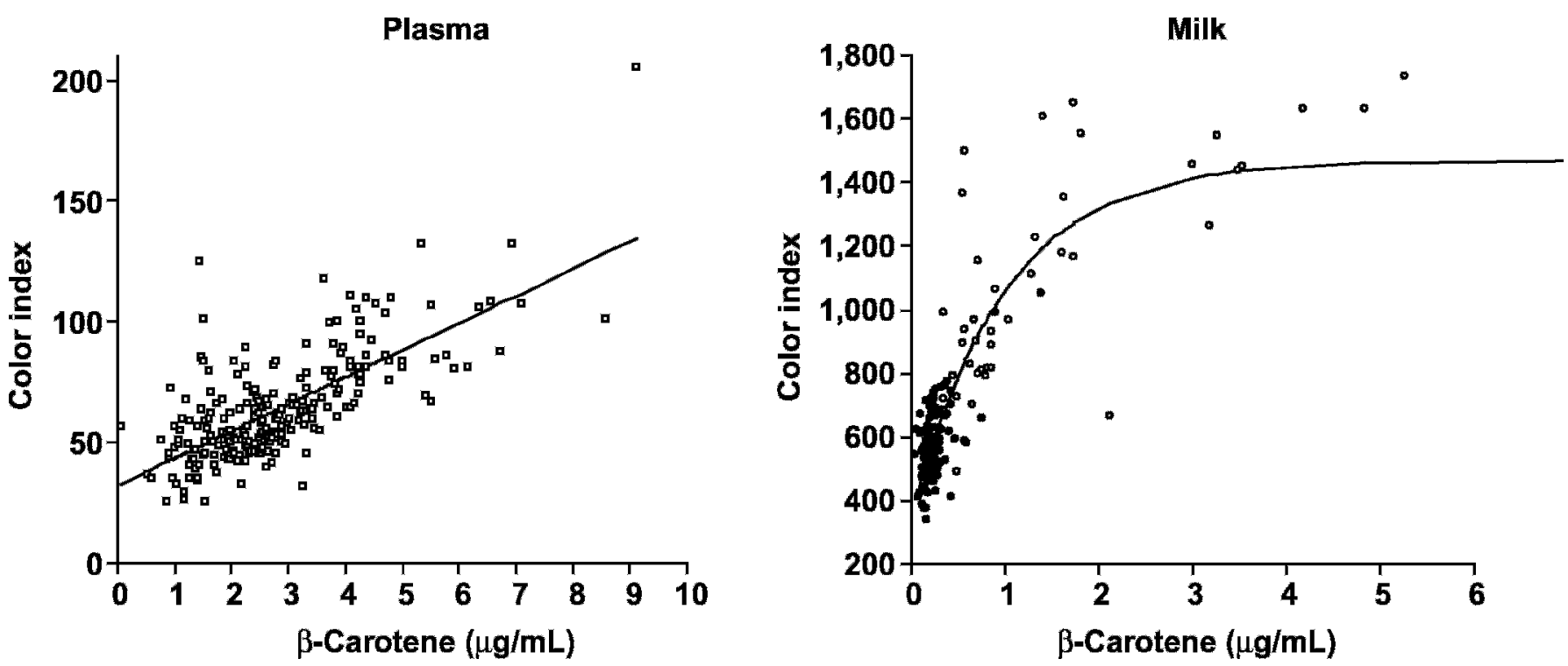

Figure 3. Relationships between $\beta$-carotene concentration $(\mathrm{BC}, \mu \mathrm{g} / \mathrm{mL})$ and color index $(\mathrm{CI})$ in plasma $(\square)$, milk $(\bullet)$, and colostrum $(\bigcirc)$ of dairy cows. Plasma: $\mathrm{CI}=32.3(\mathrm{SE} 2.3 ; P<0.001)+11.2(\mathrm{SE} 0.7 ; P<0.001) \times \mathrm{BC}\left(\mathrm{n}=231\right.$; root mean square error $\left.=15.6 ; \mathrm{R}^{2}=50.6 \%\right)$. Milk: CI $=1,469(\mathrm{SE} 34 ; P<0.001)-1,118(\mathrm{SE} 46 ; P<0.001) \times \exp ^{-\mathrm{BC}}\left(\mathrm{n}=179 ; \mathrm{RMSE}=139 ; \mathrm{R}^{2}=76.6 \%\right)$.

tercepts and the individual slopes varied significantly among animals. With these models, $R^{2}$ were higher and RMSE were lower than with the global regressions. With both global regressions and within-animal models, RMSE and $\mathrm{R}^{2}$ remained similar when total carotenoids replaced $\mathrm{BC}$ concentrations as the explanatory variable for CI in plasma, colostrum, and milk.

\section{DISCUSSION}

\section{Carotenoid Diversity in Forage, Plasma, and Milk}

As expected, carotenoid concentrations were much higher in grass silage than in corn silage (517 vs. 68 $\mu \mathrm{g} / \mathrm{g}$ of DM, respectively; Table 1), and were consistent with the concentrations reported for natural grasslands in the same area (350 to $650 \mu \mathrm{g} / \mathrm{g}$ of DM; Prache et al., 2003; Calderón et al., 2006) and for direct-cut perennial ryegrass silage (Chauveau-Duriot et al., 2005). Xanthophylls and carotene accounted for 79 and $21 \%$ of total carotenoids in grass silage, respectively, which is consistent with previous results for fresh grass (Calderón et al., 2006) or grass silage (Chauveau-Duriot et al., 2005). The diversity of xanthophylls in grass silage was consistent with the figures reported for diversified natural uplands either as fresh grass (Calderón et al., 2006) or as barn-dried hay (Cardinault et al., 2004), whereas with the same analytical method, no significant

Table 3. Relationships between $\beta$-carotene (BC) concentration (in $\mu \mathrm{g} / \mathrm{mL}$ ) and color index (CI) in plasma, colostrum, and milk of dairy cows

\begin{tabular}{|c|c|c|c|c|c|c|c|}
\hline \multirow[b]{2}{*}{ Item } & \multirow{2}{*}{$\begin{array}{l}\text { Number } \\
\text { of data }\end{array}$} & \multirow[b]{2}{*}{ Model $^{1}$} & \multirow[b]{2}{*}{ Equation } & \multicolumn{2}{|c|}{$\begin{array}{l}\text { Interaction with } \\
\text { animal }(P \text {-value })\end{array}$} & \multirow[b]{2}{*}{$\mathrm{RMSE}^{2}$} & \multirow[b]{2}{*}{$\mathrm{R}^{2}$} \\
\hline & & & & Intercept & Slope & & \\
\hline Plasma & 231 & Within-animal & $\mathrm{CI}=38.5(\mathrm{SE} 2.7)^{* * *}+8.51(\mathrm{SE} 0.98)^{* * *} \times \mathrm{BC}$ & 0.004 & 0.115 & 13.8 & 0.61 \\
\hline \multirow{2}{*}{ Colostrum } & \multirow[t]{2}{*}{51} & Global & $\mathrm{CI}=1,504(\mathrm{SE} 60) * * *-1,145(\mathrm{SE} 118)^{* * *} \times \exp ^{-\mathrm{BC}}$ & - & - & 216 & 0.65 \\
\hline & & Within-animal & $\mathrm{CI}=1,616(\mathrm{SE} 113)^{* * *}-1,537(\mathrm{SE} 391)^{* *} \times \exp ^{-\mathrm{BC}}$ & 0.185 & 0.496 & 191 & 0.73 \\
\hline Milk & 128 & Global & $\mathrm{CI}=476(\mathrm{SE} 14)^{* * *}+412(\mathrm{SE} 47)^{* * *} \times \mathrm{BC}$ & - & - & 81 & 0.37 \\
\hline Colostrum + milk & 179 & Within-animal & $\mathrm{CI}=1,480(\mathrm{SE} 37)^{* * *}-1136(\mathrm{SE} 50)^{* * *} \times \exp ^{-\mathrm{BC}}$ & $<0.001$ & $<0.001$ & 113 & 0.85 \\
\hline
\end{tabular}

\footnotetext{
${ }^{1}$ Global equation determined by regression; within-animal equation determined by variance-covariance (see the Materials and Methods
} section for details).

${ }^{2}$ RMSE $=$ root mean square error.

$* P<0.05 ; * * P<0.01 ; * * * P<0.001$. 
amounts of violaxanthin and antheraxanthin were found in grass silage prepared from cultivated monospecific swards (Chauveau-Duriot et al., 2005). Among the carotenes, only all-trans $\mathrm{BC}$ was identified in the present study. Cis $\mathrm{BC}$ was also not detected in grass silages prepared from cultivated monospecific swards (Chauveau-Duriot et al., 2005), whereas it has been reported as representing $4 \%$ (Calderón et al., 2006) to $12 \%$ (Prache et al., 2003) of total carotenoids in fresh, natural grasslands.

Carotenoids in plasma and milk consisted mainly of $\mathrm{BC}$ as all-trans and cis-13 isomers, and of lutein. Their respective proportions in plasma (69:27:4) are consistent with previous reports for dairy cows (Nozière et al., $2006 \mathrm{~b}$ ), reflecting the fact that bovines predominantly accumulate BC rather than lutein (Yang et al., 1992). It should be underlined that in the present experiment, the cis-13 isomer accounted for $30 \%$ of total $\mathrm{BC}$ in plasma despite the fact that it was not found in the feedstuffs. It is the most likely that the cis-13 isomer of $\mathrm{BC}$ would originate from microbial activities on the all-trans isomer in the rumen, as is well known for fatty acids. Studies with human subjects have indicated no significant cis-trans $\mathrm{BC}$ isomerization in the human gut (Tyssandier et al., 2003). Furthermore, data from in vitro experiments using Caco-2 cells suggest that BC cis-isomers would be absorbed less efficiently than trans-isomers (During et al., 2002). However, given the scarcity of relevant data on ruminants, it is not possible to draw solid conclusions on cis-trans $\mathrm{BC}$ isomerization in the lumen of the digestive tract (Cardinault et al., 2006; Graulet et al., 2006). Another explanation would be related to isomerization after absorption (in the enterocytes, in the liver, or in peripheral tissues), but this remains unproven. In addition, the absence of xanthophylls other than lutein in the plasma of cows fed a natural grassland diet containing these carotenoids has been reported previously (Graulet et al., 2006), but the underlying mechanisms (i.e., specificity of intestinal absorption or plasma clearance from circulating lipoproteins among carotenoids, or both) have not yet been studied.

$\beta$-Carotene and lutein accounted for 82 and $18 \%$, respectively, of total carotenoids in milk. Although it is not always the case (Nozière et al., 2006b), several authors have reported significant amounts of lutein in cow's milk, accounting for 3\% (Havemose et al., 2004) to $14 \%$ (Martin et al., 2004) of total carotenoids in cows fed on grass silage. In contrast, even with the same analytical method (Martin et al., 2004; Calderón et al., 2006; Nozière et al., 2006b), the presence of significant amounts of cis-13 BC in cow's milk (i.e., 16\% of total carotenoids in the present experiment) has, to our knowledge, never been reported previously, although traces have been detected (Lucas et al., unpublished data, as cited by Nozière et al., 2006a). The explanation for such a large amount of cis-13 BC in cow's milk in the present experiment, which may derive from either uptake from plasma cis-13 BC or from isomerization of all-trans $\mathrm{BC}$ in the mammary gland, remains unclear.

\section{Extraction of Carotenoids and Fat-Soluble Vitamins from Plasma to Milk}

Assuming a flow through the mammary gland of 400 $\mathrm{L}$ of plasma $/ \mathrm{kg}$ of milk produced (Delamaire and Guinard-Flament, 2006), the amounts of lutein, trans BC, cis $\mathrm{BC}$, vitamin $\mathrm{A}$, and vitamin $\mathrm{E}$ secreted in mature milk accounted (on average for both groups between wk 2 to 12 ) for $0.08,0.02,0.01,0.15$, and $0.02 \%$ of the daily plasma flux of these components, respectively. The higher recovery of vitamin A than $\mathrm{BC}$ or vitamin $\mathrm{E}$ is in agreement with previous reports (Jensen et al., 1999; Nozière et al., 2006b), and may reflect either a more efficient uptake of plasma vitamin A by the mammary gland or an ability of the mammary gland to cleave BC into vitamin A, as demonstrated by Schweigert and Eisele (1990). In the present work, the respective average proportions of $\mathrm{BC}$ and lutein were 96 and $4 \%$ in plasma, vs. 84 and $16 \%$ in milk. The higher proportion of lutein in milk than in plasma has also been reported in humans (Lietz et al., 2006). It could be associated either with the better efficiency of transfer of this more polar molecule from plasma lipoproteins to mammary epithelial cells and then to milk, or to the cleavage of a fraction of $\mathrm{BC}$ to vitamin $\mathrm{A}$ in the mammary gland. As observed for $\alpha$-tocopherol in rats (Martinez et al., 2002), the uptake of carotenoids and fatsoluble vitamins by the mammary gland may depend on lipoprotein lipase activity, which is the limiting step in the delivery of circulating fatty acids (as part of triacylglycerols located in the core of lipoproteins) from plasma to tissues. However, the mechanisms involved in the transfer from plasma to milk and their possible regulation have not been clearly elucidated.

\section{Changes in Carotenoids and Vitamins in Plasma and Milk During the Peripartum Period (wk -8 to 1)}

The evolution of $\mathrm{BC}$, vitamin $\mathrm{A}$, and vitamin $\mathrm{E}$ concentrations in the plasma of dairy cows during the peripartum period has previously been studied by various teams (Johnston and Chew, 1984; Michal et al., 1994; Chawla and Kaur, 2004). We observed a similar pattern for lutein, characterized by a rapid decrease in plasma concentrations occurring mainly 1 wk prepartum until the first week of lactation. This may be partly due to the moderate decrease in grass silage intake around 
parturition, but also mainly to an increased uptake of these nutrients during the peripartum period, particularly, but not exclusively (Goff et al., 2002), by the mammary gland for subsequent colostrum secretion (Goff and Stabel, 1990). With the HH group, milk fat concentrations of all these micronutrients were much higher in colostrum ( $\mathrm{d} 1$ ) than in mature milk ( 7 to 84 ); that is, 1.6-, 9.9-, 1.5-, and 4.0-fold higher for lutein, BC, vitamin $\mathrm{A}$, and vitamin $\mathrm{E}$, respectively. The importance of their supply by colostrum is emphasized by the very low plasma concentrations of these micronutrients in newborn calves, regardless of the diet fed to the cows before calving.

The switch from grass silage to corn silage at the beginning of the drying-off period for the LH group induced a rapid decrease in plasma carotenoid and vitamin E concentrations, averaging -0.08 and $-0.07 \mu \mathrm{g} /$ $\mathrm{mL}$ per $\mathrm{d}$, respectively, between $\mathrm{d}-56$ and -28 . This group $\times$ time interaction is consistent with the results obtained in midlactation on dairy cows switched from grass silage to late hay diets (Nozière et al., 2006b), although the rates of decrease were higher in this latter study $(-0.21$ and $-0.12 \mu \mathrm{g} / \mathrm{mL}$ per $\mathrm{d}$, respectively). Although the supply of BC was 3.8-fold higher with grass silage than with corn silage-based diets, plasma vitamin A, which accounts for both ester derived from dietary intake and alcohol derived from the liver (Tomlinson et al., 1974), tended to be lower in the $\mathrm{HH}$ group than the LH group during the drying-off period, but the differences were not statistically significant. The same differences in plasma carotenoid and vitamin concentrations between $\mathrm{HH}$ and $\mathrm{LH}$ during the dryingoff period were also observed in the colostrum. The differences in $\mathrm{BC}$ concentrations between $\mathrm{HH}$ and $\mathrm{LH}$ observed at calving in both plasma and colostrum disappeared after the first $5 \mathrm{~d}$ following the switch from corn to grass silage, indicating a rapid net accumulation of mainly diet-derived $\mathrm{BC}$ on lipoproteins during this period. This explained that no significant group $\times$ time interactions were observed in plasma and milk during lactation.

\section{Evolution of Carotenoids and Vitamins in Plasma and Milk During Lactation}

Plasma lutein, BC, vitamin A, and vitamin E concentrations increased over time during the lactation period. Similar results have already been reported for BC, retinol, and $\alpha$-tocopherol by Jensen et al. (1999) in primiparous cows fed a silage-fodder beet-based diet in early lactation. In the present study, vitamin $\mathrm{A}$ and $\mathrm{E}$ concentrations increased in parallel with forage intake, whereas $\mathrm{BC}$ concentrations were not stabilized at the end of the experiment. Although they are positively related to intake, a specific effect of lactation stage on plasma BC and vitamin E levels cannot be excluded. Patterson (1965) reported a positive correlation between plasma NEFA and BC in peripartum stall-fed cows, suggesting that $\mathrm{BC}$ is restored by adipose tissues during lipid mobilization. Also, epinephrine-stimulated lipid mobilization has been shown to induce a concomitant decrease in $\mathrm{BC}$ concentrations in bovine adipose explants (Arias et al., 2005), and feed restriction has been demonstrated in vivo to release vitamin $\mathrm{E}$ from labile pools (Nockels et al., 1996). In the present study, we found no significant relationships between plasma NEFA and BC or vitamins, but this result does not preclude a concomitant restoration of these micronutrients via hepatic or adipose stores.

After the drastic fall occurring during the first week of lactation, the changes between wk 1 and 12 in lutein, $\mathrm{BC}$, vitamin $\mathrm{A}$, and vitamin $\mathrm{E}$ concentrations in milk fat $(+23,+2,-8$, and $+49 \%$, respectively, between $\mathrm{d} 7$ and 84, assuming linearity) as well as their yield in milk $(+8,-6,-17$, and $+30 \%$, respectively) were much lower than in plasma concentrations $(+36,+57,+40$, and $+80 \%$, respectively). This result is in line with $\mathrm{BC}$ secretion models based on milk fat (Waghorn and Knight, 1992) or color (Winkelman et al., 1999) measurements. In contrast, the present results clearly diverge from Jensen et al. (1999), who reported increased concentrations of retinol, $\mathrm{BC}$, and $\alpha$-tocopherol in milk fat throughout the first 6 mo of lactation in primiparous cows. Furthermore, the BC and vitamin E levels reported here were nearly 3 - to 4 -fold higher and 2- to 3 fold lower, respectively, than in the study by Jensen et al. (1999), whereas plasma concentrations were comparable between both studies. A parity effect (primiparous vs. multiparous) on the ability of the mammary gland to extract these micronutrients has not yet been demonstrated. Differences between experiments suggest that in the study by Jensen et al. (1999), where intake was not monitored, the effects of micronutrient intake and lactation stage were confounded.

\section{Relationships Between Color and BC}

Variations in CI mirrored the variations in BC concentrations in both plasma and milk. The relationships between $\mathrm{BC}$ (or total carotenoids) and CI showed that $\mathrm{BC}$ was the main carotenoid responsible for plasma and milk color. The relationship between $\mathrm{BC}$ and $\mathrm{CI}$ was linear over a wide range of $\mathrm{BC}$ concentrations (0.06 to $9.11 \mu \mathrm{g} / \mathrm{mL}$ ) in plasma, whereas it was nonlinear over a wide range of concentrations $(0.05$ to $5.27 \mu \mathrm{g} / \mathrm{mL})$ in the pooled milk + colostrum data set, indicating a saturation of signals provided by reflectance in highly concentrated milk samples, and particularly in colos- 
trums. Linear relationships have previously been reported in milk over a much lower range of $\mathrm{BC}$ concentrations (0 to $0.35 \mu \mathrm{g} / \mathrm{mL}$; Nozière et al., 2006a). Withinanimal models led to much more precise relationships, and revealed that the relationships between $\mathrm{BC}$ and CI vary among individuals. High individual variations of both $\mathrm{BC}$ and color in plasma and milk, related to genetic factors, have also been reported (Jensen et al., 1999; Winkelman et al., 1999; Morris et al., 2002). The results of the present work confirm, over a wide range of $\mathrm{BC}$ concentrations, that such a relatively straightforward method of color determination is unable to accurately assess $\mathrm{BC}$ concentrations in plasma and milk, possibly because of the presence of undetected molecules (isomers or metabolites) absorbing between 450 and $530 \mathrm{~nm}$.

Because BC concentrations in the plasma and milk of dairy cows are closely related to the nature of forage provided (reviewed by Nozière et al., 2006a), CI in plasma and milk have been presented as an interesting perspective for tracing feeding management of dairy cows (Martin et al., 2005a; Nozière et al., 2006b). As observed for BC, the variations in CI between $\mathrm{d} 7$ and 84 (+27 and -57 units for plasma and milk, respectively) were not negligible compared with the variations related to diet composition reported here (+31 units for plasma between $\mathrm{LH}$ and $\mathrm{HH}$ ) and in a previous study (+25 and +110 units for plasma and milk, respectively, between hay and grass silage, Nozière et al., 2006b). The present study underlines that, from a traceability of feeding management standpoint, variations in CI related to lactation stage may interfere with the results and thus need to be factored in, particularly when preserved forages are compared.

\section{CONCLUSIONS}

The present study showed that following a strong decrease occurring during the first few days of lactation, carotenoids and vitamin $\mathrm{A}$ and $\mathrm{E}$ concentrations increased strongly in the plasma of dairy cows fed a grass silage diet during the first 3 mo of lactation, parallel to intake. These variations depended only transitorily on the nature of the forage fed during the dry period, indicating that plasma concentrations of these fat-soluble micronutrients involved in the nutritional or sensorial quality of milk and dairy products mainly depended on the dietary supply, even during the period of lipid mobilization. In contrast with plasma, carotenoids and vitamin $\mathrm{A}$ and $\mathrm{E}$ concentrations varied only slightly across time in mature milk, suggesting that the efficiency of their transfer from plasma to milk varied throughout the stage of lactation. The variations in $\mathrm{BC}$ concentrations were responsible for a substantial proportion of the variations in the CI of plasma and milk. The changes in CI during the first 3 mo of lactation were not negligible compared with the variations related to the nature of forage reported in previous studies. Consequently, the methods being developed for the traceability of feeding management of dairy cows based on direct or indirect characterization of these micronutrients in milk or plasma will need to account for changes related to lactation stage, which needs to be elucidated by further investigation.

\section{ACKNOWLEDGMENTS}

We wish to thank D. Roux and the staff at "Les Cèdres" for animal care, zootechnical measurements, and sampling; F. Anglard and P. Amblard for determination of CI and the NEFA; and Société Française d'Exportation des Ressources Éducatives, Cosejo Nacional de Ciencia y Tecnología and the Colegio de Postgraduados en Ciencias Agrícolas-Mex. for financial support.

\section{REFERENCES}

AOAC. 1990. Official Methods of Analysis. 14th ed. Vol. 1. AOAC, Washington, DC.

Arias, E., A. Gonzales, A. Shimada, A. Varela-Echeverria, A. During, and O. Mora. 2005. Beta-carotene level is associated with triglyceride content in bovine adipose tissue. Page 87 in Proc. 14th Int. Symp. Carotenoids, Edinburgh, UK. Int. Carotenoid Soc.

Baldi, A. 2005. Vitamin E in dairy cows. Liv. Prod. Sci. 98:117-122.

Calderón, S. F., G. Tornambé, B. Martin, P. Pradel, B. ChauveauDuriot, and P. Nozière. 2006. Effects of mountain grassland maturity stage and grazing management on carotenoids in sward and cow's milk. Anim. Res. 55:533-544.

Cardinault, N., M. Doreau, and P. Nozière. 2004. Fate of carotenoids in the rumen. Renc. Rech. Rumin. 11:82.

Cardinault, N., M. Doreau, C. Poncet, and P. Nozière. 2006. Digestion and absorption of carotenoids in sheep given fresh red clover. Anim. Sci. 82:49-55.

Chauveau-Duriot, B., D. Thomas, J. Portelli, and M. Doreau. 2005. Carotenoids content in forages: Variation during conservation. Renc. Rech. Rumin. 12:117.

Chawla, R., and H. Kaur. 2004. Plasma antioxidant vitamin status of periparturient cows supplemented with $\alpha$-tocopherol and $\beta$ carotene. Anim. Feed Sci. Technol. 114:279-285.

Delamaire, E., and J. Guinard-Flament. 2006. Longer milking intervals alter mammary epithelial permeability and the udder's ability to extract nutrients. J. Dairy Sci. 89:2007-2016.

During, A., M. M. Hussain, D. W. Morel, and E. H. Harrison. 2002. Carotenoid uptake and secretion by Caco- 2 cells: $\beta$-Carotene isomer selectivity and carotenoid interactions. J. Lipid Res. 43:1086-1095.

Goff, J. P., K. Kimura, and R. L. Horst. 2002. Effect of mastectomy on milk fever, energy, and vitamin $\mathrm{A}, \mathrm{E}$, and $\beta$-carotene status at parturition. J. Dairy Sci. 85:1427-1436.

Goff, J. P., and J. R. Stabel. 1990. Decreased plasma retinol, $\alpha$ tocopherol, and zinc concentration during the periparturient period: Effect of milk fever. J. Dairy Sci. 73:3195-3199.

Graulet, B., B. Chauveau-Duriot, P. Nozière, and M. Doreau. 2006. Carotenoid amounts and composition in digestive contents and plasma of cows. Renc. Rech. Rumin. 13:193.

Havemose, M. S., M. R. Weisbjerg, W. L. P. Bredie, and J. H. Nielsen. 2004. Influence of feeding different types of roughage on the oxidative stability of milk. Int. Dairy J. 14:563-570. 
INRA (Institut National de la Recherche Agronomique). 1981. Prévision de la Valeur Nutritive des Aliments des Ruminants. Tables de prévision de la valeur alimentaire des fourrages. Ed. INRA Publications, Versailles, France.

INRA (Institut National de la Recherche Agronomique). 1989. Ruminant Nutrition. Recommended Allowances and Feed Tables. R. Jarrige, ed. INRA, Paris, France.

Jensen, S. K., A. K. B. Johannsen, and J. E. Hermansen. 1999. Quantitative secretion and maximal secretion capacity of retinol, $\beta$-carotene and $\alpha$-tocopherol into cows' milk. J. Dairy Res. 66:511-522.

Johnston, L. A., and B. P. Chew. 1984. Peripartum changes of plasma and milk vitamin $\mathrm{A}$ and $\beta$-carotene among dairy cows with or without mastitis. J. Dairy Sci. 67:1832-1840.

Lietz, G., G. Mulokozi, J. C. K. Henry, and A. M. Tomkins. 2006. Xanthophyll and hydrocarbon carotenoid patterns differ in plasma and breast milk of women supplemented with red palm oil during pregnancy and lactation. J. Nutr. 136:1821-1827.

Lyan, B., V. Azais-Braesco, N. Cardinault, V. Tyssandier, P. Borel, M. C. Alexandre-Gouabau, and P. Grolier. 2001. Simple method for clinical determination of 13 carotenoids in human plasma using an isocratic high-performance liquid chromatographic method. J. Chromatogr. B. 751:297-303.

Martin, B., A. Cornu, N. Kondjoyan, A. Ferlay, I. Verdier-Metz, P. Pradel, E. Rock, Y. Chilliard, J. B. Coulon, and J. L. Berdagué. 2005a. Milk indicators for recognizing the types of forages eaten by dairy cows. Pages 127-136 in Indicators of Milk and Beef Quality. EAAP Publ. no. 112. J. F. Hocquette and S. Gigli, ed. Wageningen Academic Publishers, Wageningen, the Netherlands.

Martin, B., V. Fedele, A. Ferlay, P. Grolier, E. Rock, D. Gruffat, and Y. Chilliard. 2004. Effects of grass-based diets on the content of micronutrients and fatty acids in bovine and caprine dairy products. Grassl. Sci. Eur. 9:876-886.

Martin, B., I. Verdier-Metz, S. Buchin, C. Hurtaud, and J. B. Coulon. $2005 \mathrm{~b}$. How does the nature of forages and pasture diversity influence the sensory quality of dairy livestock products? Anim. Sci. 81:205-212.

Martinez, S., C. Barbas, and E. Herrera. 2002. Uptake of alphatocopherol by the mammary gland but not by white adipose tissue is dependent on lipoprotein lipase activity around parturition and during lactation in the rat. Metabolism 51:1444-1451.

Michal, J. J., L. R. Heirman, T. S. Wong, and B. P. Chew. 1994 Modulatory effects of dietary $\beta$-carotene on blood and mammary leukocyte function in periparturient dairy cows. J. Dairy Sci. 77:1408-1421.

Morris, C. A., T. W. Knight, S. A. N. Newman, S. M. Hickey, A. F. Death, K. T. O'Neill, and M. Ridland. 2002. Genetic studies of carotenoid concentration in the plasma and milk of New Zealand dairy cattle. N. Z. J. Agric. Res. 45:27-33.

Nockels, C. F., K. G. Odde, and A. M. Craig. 1996. Vitamin E supplementation and stress affect tissue $\alpha$-tocopherol content of beef heifers. J. Anim. Sci. 74:672-677.

Nozière, P., B. Graulet, A. Lucas, B. Martin, P. Grolier, and M. Doreau. 2006a. Carotenoids for ruminants: From forages to dairy products. Anim. Feed Sci. Technol. 131:418-450.

Nozière, P., P. Grolier, D. Durand, A. Ferlay, P. Pradel, and B. Martin. 2006b. Variations of carotenoids, fat soluble micronutrients and color in cows' plasma and milk following changes in forage and feeding level. J. Dairy Sci. 89:2634-2648.

Patterson, D. S. 1965. Plasma carotenoids and fat mobilization in stall-fed cattle. Nature 206:1069.

Prache, S., A. Priolo, and P. Grolier. 2003. Persistence of carotenoid pigments in the blood of concentrate-finished grazing sheep: Its significance for the traceability of grass-feeding. J. Anim. Sci. 81:360-367.

Prache, S., A. Priolo, H. Jailler, H. Dubroeucq, D. Micol, and B. Martin. 2002. Traceability of grass-feeding by quantifying the signature of carotenoid pigments in herbivores meat, milk and cheese. Grassl. Sci. Eur. 7:592-593.

SAS Institute. 2000. SAS/STAT. User's Guide. SAS Institute Inc., Cary, NC.

Schweigert, F. J., and W. Eisele. 1990. Parental beta-carotene administration to cow: Effect on plasma levels, lipoprotein distribution and secretion in the milk. Z. Ernahrungswiss. 29:184-191.

Tomlinson, J. E., G. E. Mitchel Jr., N. W. Bradley, R. E. Tucker, J. A. Bowling, and G. T. Schelling. 1974. Transfer of vitamin A from bovine liver to milk. J. Anim. Sci. 39:813-817.

Tyssandier, V., E. Reboul, J. F. Dumas, C. Bouteloup-Demange, M. Armand, J. Marcand, M. Sallas, and P. Borel. 2003. Processing of vegetable-borne carotenoids in the human stomach and duodenum. Am. J. Physiol. Gastrointest. Liver Physiol. 284:G913G923.

Waghorn, G. C., and T. W. Knight. 1992. Beta-carotene intake, digestion, absorption and metabolism in the dairy cow. Pages 42-49 in Summary of Proc. Milkfat Flavour Forum. New Zealand Dairy Research Institute, Palmerston North, New Zealand.

Winkelman, A. M., D. L. Johnson, and A. K. H. MacGibbon. 1999. Estimation of heritabilities and correlations associated with milk color traits. J. Dairy Sci. 82:215-224.

Yang, A., T. W. Larsen, and R. K. Tume. 1992. Carotenoid and retinol concentrations in serum, adipose tissue and liver and carotenoids transport in sheep, goats and cattle. Aust. J. Agric. Res. 43:1809-1817. 